\title{
Edutainment Games for Mobile Multimedia Museum Guidance Systems: A Classification Approach
}

\author{
Areti Damala \\ CEDRIC / CNAM, \\ 282 rue Saint-Martin, Paris, France \\ areti.damala@gmail.com
}

\begin{abstract}
This paper proposes a first sketch on the state of the art regarding interactive edutainment games delivered through mobile multimedia museum guidance systems used in the context of a cultural visit. The goal is to identify current practices but also potential functional requirements, through the introduction of a first set of classification criteria emerging from a literature review of representative projects. The issue of related evaluation practices is also discussed.
\end{abstract}

Keywords: mobile learning, edutainment, mobile museum guides, games.

\section{Introduction and Motivation for Research}

About one third of museum and gallery audiences are made up by children accompanied by their families. As interactivity and action is vital for children, a perception that the museum visit will be fun is crucial. In this context, educational games for museum handheld devices may constitute an alternative to PDA-escorted guided visits, especially attractive for children and adults by triggering curiosity and promoting engagement physically, mentally and emotionally [1].

\section{A First Set of Classification Criteria}

Multimedia games for museum handheld devices can be solitary games (e.g. [2, 3]) or team games $[4,5,6,7]$. Teams can be consisted of individuals [4, 5] or groups of two or more players $[5,6,7]$. When teams or team members are given the possibility to communicate between them, communication can be synchronous -as is more often the case- or asynchronous [2]. Another distinction can be made according to whether the game proposes the use of one or multiple delivery platforms [7] such as stationary workstations, video projectors or head mounted displays [4]. The environment in which the game takes place can also be used for classification purposes; three categories can be distinguished: outdoor games in cities, historical or archaeological sites [4], indoor games in museums and galleries [5, 6, 7] and games that combine tasks that should be accomplished both in an indoor and an outdoor environment [7]. Similarly, the games can also take place in a variety of computer environments: 2D environments, 3D environments, Augmented Reality environments or combinations of the above [7]. The examined games are often 
inspired by already well known educational museum games, like "treasure hunts" and observation games $[4,7]$ or mystery/detective games, in which the players have to solve a mystery case regarding one or several museum objects $([4,5])$. According to the nature of the proposed activities, edutainment applications for mobile multimedia museum guidance systems can be also distinguished in observation games, reflection games or video/arcade games [2]. Finally it should be noted that additional activities are sometimes also proposed for the pre- and post-visit phases [3].

\section{Perspectives and Directions for Future Work}

Games can provide an important ally in mobile museum guides' and edutainment projects. However, the number of evaluation studies carried out regarding edutainment interactive applications on museum handheld devices is significantly inferior to this concerning the effectiveness of use of mobile multimedia museum guides. In addition, scarce are the studies regarding the effectiveness of PDA delivered educational games as compared with more "traditional", educational, paper and pencil quests. Hence, the urge to further invest in the conception, assessment and evaluation of mobile museum guides' edutainment applications is crucial.

\section{References}

1. Damala, A.: Design Principles for Mobile Museum Guides Using Visitor Studies and Museum Learning Theories. In: Proceedings of the 2007 IADIS M-Learn Conference (Mobile Learning), Lisbon, Portugal, pp. 277-281 (2007)

2. Belotti, F., Berta, R., De Gloria, A., Margarone, M.: User Testing a hypermedia tour guide. Pervasive Computing Journal 1(2), 33-41 (2004)

3. Sauer, S., Goebel, S.: Dinohunter: Game based learn experience in Museums. In: ICHIM 2003, non-paginated document. Archives and Museum Informatics Europe, Paris (2003)

4. Hall, T., Ciolfi, L., Bannon, L., Fraser, M., Benford, S., Bowers, J., Greenhalgh, C., Hellström, S., Izadi, S., Schnädelbach, H., Flintham, M.: The Visitor as Virtual Archaeologist: Explorations in Mixed Reality Technology to Enhance Educational and Social Interaction in the Museum. In: Virtual Reality, Archeology, and Cultural Heritage 2001, pp. 91-96. ACM Press, New York (2001)

5. Broadbent, J., Marti, P.: Location Aware Mobile Interactive Guides: Usability Issues. In: International Cultural Heritage Informatics Meeting ICHIM 1997, pp. 15-30. Archives and Museum Informatics Europe, Milano (1997)

6. Thom-Santelli, J., Boehner, K., Gay, G., Hembrooke, H.: Beyond just the facts: transforming the museum learning experience. In: CHI 2006, Human Factors in Computing Systems, pp. 3214-3222. ACM Press, New York (2006)

7. Laurillau, Y., Paternó, F.: Supporting Museum Co-visits Using Mobile Devices. In: Brewster, S., Dunlop, M.D. (eds.) Mobile HCI 2004. LNCS, vol. 3160, pp. 451-455. Springer, Heidelberg (2004) 